\title{
PHILOSOPHICAL APPROACH TO THE STATUTORY DRAFTING
}

\begin{abstract}
This article traces the relationship between the law-making process and narratives. Undoubtedly, how statutes are created is a constitutional question, yet the Constitution regulates only part of this process. Constitution or any statute does not regulate parts of the legislative process implemented by the government (mostly preliminary phases). However, they are important and influence the remaining parts of the law-making process. This government's activity is the sphere of informal regulation hidden from the primary control of the public. This article explores the importance of the bureaucratic elements of the law-making process with emphasis on a narrative approach: narratives justify legislature. How can we overcome the two lines of narratives - one produced by global capital and the other represented by national experience?
\end{abstract}

Keywords: legislation, new constitutionalism, narratives, bureaucracy, statutory drafting.

\section{INTRODUCTION}

The continental (civil law) legal system is based on written law - primarily statutes. A statute as a source of law is often subjected to many investigations and scientific attention, and deserving attention is also paid to the legislative process. In modern democratic states, the legislative process is entrusted in the hands of parliaments. These parts of the process are controlled and observed by mass media, public, or other relevant political actors. In reality, essential parts of the process are delegated to administrative agencies. The authority in law-making is delegated to the government or other administrative agencies (Calabresi 1982, 1). However, the bureaucratic phases of the legislative process are covered merely to some extent. In essence, sociological examinations of how drafts of statutes are prepared before they enter parliament (or another legislative authority) and what kind of relationships accompany them in the system of executive power are particularly unrepresented. Such distinguished authors as Francis Bacon (Bacon 1785), Charles de Montesquieu (Montesquieu 1777), Jeremy Bentham (Bentham 1843), and Friedrich Carl von Savigny (Savigny 1999) elaborated prescriptive analyses of how statutes ought to be drafted. This enumeration of authors shows that there are many prescriptive theories for the drafting process but an insufficient number of descriptive approaches describing how legal experts behave when

\footnotetext{
* Masaryk University, Faculty of Law, Department of Legal Theory, skop@law.muni.cz.
} 
drafting a statute. Legal theory determines how statutes should be written but pays no attention to how statutes are indeed written.

The attention paid to the formal legislative process structures is understandable concerning constitutional patterns of legislation. The "will of the people" as a source of justification of power in any Rechtstaat, targets parliaments directly and governments or other administrative authorities indirectly. In parliaments, there are visible power struggles, and the exercise of power there is under the highest democratic control. However, laws are frequently drafted or (physically) written by government bodies (through government proposals proposed to the parliament) and only then are discussed in parliament. These stages of the legislative process, where the power struggles and informal regulation is relevant as well, are beyond the accustomed research interest. This article should seek te symbolic world of real lawmakers (Wronkovska 1987), which is more hidden from the eyes of the public, among the government bodies.

\section{INFORMAL REGULATION}

Constitutional provisions regulate administrative parts of the legislative process not sufficiently, while general proclamations are dominant. So many informal regulations regarding language, process, or affected members of legislation are part of "invisible discourse" (Krygier 1988, 28), which is beyond the observed target. These government actors (legal experts employed by government departments) represent a mixture of the bureaucratic apparatus (Robinson 1991) and political influencers. Although most attention and critique focus on parliaments and these stages of the legislative process, the monitoring of (un)ethical activities, suspicious behavior, right/wrong ideas, the same attention should be dedicated to the administrative stages of the legislative process. Cultural determinants are relevant in both these parts of the legislative process (see, e.g., Paulus 1974; Krygier 1988, 29), influencing any preparatory or drafting stage of the legislative process. To understand the legislature means to understand the symbolical patterns of these stages and to understand the participating legal experts. Statutes are not existing in any vacuum: it is crucial to identify relevant actors and their symbolical world, determining the content of the statute. Legislative experts state that their work is regulated not only by legal rules but also by informal regulation: customs, conventions, politics. (Škop, Vacková 2019) For interpreting persons, it is essential to know what are informal rules regulating legislative process - why the phrase is written in a particular style, why are ideas expressed in such a form, or what is the context of the statute. Even the judiciary can take advantage of this knowledge and follow methods of interpretation, taking into account the real lawmakers (see Sullivan 2007, 42; Borowicz 2009; Bielska-Brodziak 2017). More critically, legal experts make up a community sharing the knowledge of correct interpretation 
(e.g., see Mańko 2018, 107), and this knowledge is used on both sides of the barricade - interpretation and creation.

For a deep understanding of the legislative process, it is essential to identify informal rules participating in legislative behavior. The creation of binding legal texts is, on the one hand, bound by codified rules and, on the other hand, depends on many informal techniques and practices. The environment of the legislative process is open to typically informal negotiations, and it has features typical of informal groups. It is a behavior based on custom or a long and unwritten tradition to which the creation of texts is subject. At least in some areas of law, it is possible to identify actors generally considered as authorities of the field, and their expressed consent is understood as a guarantee of the continuity of the process. The ability to orientate oneself in informal relations and understand power character is a fundamental experience of every legislator (Škop et al. 2019, 196). These power relations are part of the legal system (culture), and without them, the description of the legal system is incomplete.

The real lawmakers give the statutes their fundamental shapes and ideas through forming their entirety and harmonizing the values related to specific acts and legislation as a whole. Moreover, the parliamentary stages are under the strict control of the public, political parties, or the Constitutional Court. The governmental steps are somewhat hidden - they take place in the offices of various departments, and their partial outcomes remain unpublished. Nevertheless, this does not mean that these parts are less critical or lack any relevance outside established relationships. The governmental stages of the law-making process should be investigated for at least the following reasons: costs, regulation, and the attributes of the real lawmakers, anthropological considerations, and matters of communication.

Statutory regulation is not cost-free - the financial consequences of the regulation should be taken into regard for every process. In the beginning, at the governmental level, it is easy to reject expensive rules. However, if policies are set, it is difficult to rise against justified policy and regulation. One of the many features of modern law is the reproduction of regulation. Modern parliaments can be presented as factories where proposals run on a conveyor belt and are then transformed into legal regulations. The multiplication of control is used as measurable proof of the success of a government or parliament, yet more regulation means high costs. The same can be said about regulation - the modern state is obsessed by planting and cultivating a society (Baumann 1989) supported through the growth of administration-style regulation and results in a growing set of regulation that needs to be controlled. From a critical perspective, it means the creation of obedient bodies and, as a result, obedient minds (Foucault 1979).

The unknown essential attributes of real lawmakers are those that influence the content of legislation. It can be fruitful to know these attributes - even if they are general attributes characterizing a single legal community - to understand 
statutes. The possible anthropological considerations can be represented by the concept of skeletonization developed by the American anthropologist Clifford Geertz. Geertz asserted that statutory regulation creates importance (Geertz 1973) in the sense that what is regulated is essential. Statutes comprise a set of crucial objects worthy of management. What law contains (objects or characteristics) must be distinguished: any other object or aspects can be omitted. A real lawmaker must have the impression that something is worthy of regulation, and must then persuade parliament to accept this cultural importance. If some object is regulated by law means this object is significant to society.

Real lawmakers (the legal experts participating in the legislative process in its primary stages) form parts of power relations (Bourdieu 1991; Bourdieu 1999; Bourdieu, Johnson 1993). In pilot interviews conducted with legal experts in government legislative departments, the legal experts confirmed that they understand their position. At these stages of the process, it is concealed mostly through language and operations with language, or in the social context means the process of negotiation with other departments or other legal experts. They enter the juridical field and conduct battles to define the content of legal concepts (Bourdieu 1987, 816-817) or create special regulation. They exist within the structure and distribution of capital, enabling them to succeed and push through their own opinions about regulation, which is, according to Bourdieu, characteristic for the juridical field (Bourdieu 1996, 231). Besides, of course, statutes are a specific form of communication (Cover 1985; Cover 1983). By propounding statutory drafts to parliament, the government can set the agenda and give symbolic importance to specific social issues or topics. This kind of initiation of the legislative process can even establish a relevant context for interpretation and other power battles.

\section{NARRATIVES OF GLOBAL AND NATIONAL REGULATION LEVELS}

Any statutory regulation is related to narratives (see, e.g., Tait, Norris 2011, 11), and these narratives represent the legislative history of the legitimization of particular regulation. In the current situation, these narratives move from a global to a local level and vice versa. Power battles accompanying legislation and the legal sphere are conducted at many competing levels (local, national, European, international), necessarily disturb certainty and enable the questioning of the fundamental legal narratives of liberal society. Questions seeking to uncover the relationships between global regulation and national regulation create manifold new narratives that compete in a single context. The new constitutionalism opens space for the global free market, the free circulation of capital, the free distribution of the labor force, conflicts with protectionism, or cultural determinants developed at the national level. Narratives enable the addressees to understand the context of regulation and to understand the wills of the lawmakers. In a situation where 
global and national narratives compete, it is difficult to find stable interpretative guidelines - as well as to find instructions for coding rules. Without such instructions, it becomes difficult to code/decode in the same context and to share the same content of regulation. Coding and decoding, meaning constructing laws in general language and interpreting them according to given cultural patterns, are epistemological processes determined by cultural context. Without a strong narrative given by the European Union, it is difficult to transpose directions to the everyday behavior of actors at the national level. Without narrative, they will be confused about how to interpret the regulation.

The French philosopher Jean Baudrillard argued in favor of the visible past and the apparent myth of origin as necessary conditions for reassurance as to our ends (Baudrillard 1994, 10). The history enables addressees to trace the trajectory of the law - it helps in understanding the legitimization narratives of any legal system. The legal tradition, interpretation, and the practice of law are very closely connected with the law's history and its specific meanings (Krygier 1988, 30). If the past rooted in the language is forgotten, particular patterns of any national law can be overlooked too. As observed by Clifford Geertz, only the mental object capable of being expressed in a universal general language is relevant (Geertz 1973, 172). The particular world of law is subordinate to the universal and globally shared vision of ideal law. Nevertheless, the global tendencies of global capital try to break these cultural specifics in favor of a unified system with unified understandings.

In his 1936 essay The Storyteller (der Erzähler), the German philosopher Walter Benjamin declared the decline of narratives. He thought that the ability to tell stories is disappearing because no one wants any experience communicated through stories. Benjamin believed that the art of storytelling was going because the truth had lost its epic dimension (Benjamin 1988, 87). What remains is only information without any moral or value aspect. The German economic sociologist Wolfgang Streeck reviewed this attitude: narratives did not disappear, but only changed. Modern narratives are "opportunistically adaptable" to actual politics or political goals (Streeck 2017, 15). As constructs, they are subordinated to permanent change. In law, there are narratives still alive despite Benjamin's skepticism. Without narrative, the law should lose its character. The reason is the unique nature of the law, which is closely intertwined by knowledge, interpretation, and argumentation (Brooks 2002, 4). Every legal norm is a story about good and bad behavior. Narratives are essential to incorporate the law into the real-world - without narratives, it is impossible to combine the normative (ideal) world with the real world (Cover 1983, 4-5). Without narratives, the law becomes inoperable.

In 1979 essay The Postmodern Condition: A Report on Knowledge JeanFrançois Lyotard (1984) described the end of "grand narratives": no more metanarratives are legitimizing the world. Lyotard wanted - inspired by a common 
intention of critical movements based on structuralism and Marxism or NeoMarxism - to open the eyes of people blinded by the false Enlightenment's rationality. One of those grand narratives was (or is) also about global values, universal rationality, and the free mind of humans. However, this critique was incompatible with the free market, global economics, and other achievements of worldwide liberalism and new constitutionalism. Mass consumption and global economic capital need rational processes and masses open to consumption. No liberated person is required anymore because a liberated person is more resistant to the seduction of consumer society.

After the commencement of the decline of grand narratives, postmodernism (or critical theory in general) faced massive attacks. The guardians of traditional values (whoever and whatever they may be) started to accuse postmodernism of being excessively pluralist, nihilistic, or over-theoretic. Postmodernism started to be perceived as something problematic, and unfamiliar to the European thought tradition or modern rationality (e.g., Benedict XVI 2009; Dawkins 1998; McKinley 2000). Through this critique of critique, these guardians (more than postmodernism) of sanity (or common reason) reintroduced metanarratives. In the name of increasing knowledge and a return to common sense, the postmodern critique became delegitimized. After this attack, it was easy to perceive post-structuralism (or neo-structuralism) as over-scientific, over-theoretical, or incomprehensible. The postmodern erosion of grand narratives was substituted by a multiplicity of grand narratives reintroduced by the "traditional" control mechanism - mechanisms not far removed from those described by Louis Althusser (2014) as repressive state apparatuses. After a theoretical attempt to highlight problematic parts of the Enlightenment rationality, western societies faced the subsequent reification or alienation (Lukács 1971).

As seen before, the legitimization of statutory regulation is legitimization through narratives. It is caused not only by the importance of statutes as a primary regulatory means in the continental legal system but also by its symbolic significance. Hence statutory drafting is a complex process impacting culture and society - as a source and as an object. From its very beginning, no statute should exist without the appropriate legitimization. Any legal expert composing a statutory draft must use narratives rooted in the culture not only to legitimate the outcomes but also to prepare it to be understandable to its audience. However, if there are no metanarratives, where to find a unifying story shared by the real lawmaker and the audience? Can this absence of rationality as one of the narratives in the law-making lead to erosion of the legal system? Probably not. Nevertheless, it can open the doors to any regulation the political elites will need. 


\section{CULTURAL LEGITIMATION OF LAW AND LAW-MAKING}

A statute - as well as any written law - should not exist without cultural legitimation, at least as regards language. The normative language must follow the concept of the language in the environment in which the law should exist. These language rules originating in culture must be obeyed in the writing process as well in the interpretation process. The reader (audience, addressee) of a legal text must be an actual reader who picks up and reads the text, and the message must be encoded in such a way that they understand it. Any law must have its readers to be a valid legal norm, and any lawmaker (legal expert) needs the image of this reader to compose the text (see Smejkalová, Škop 2017). Here again, we can identify the outcomes of power battles: a reader can be constructed. The law - hand in hand with the legal apparatus - trains its addressees to be able to identify the content of the normative text. A reader constructed by the author or by the text itself is presupposed to be a model reader (as shown by Eco 1981), one shaped, or raised by the author or by the text itself.

Cultural legitimization provides rules on how to interpret and integrate (culturally) the creator and the audience. The law, the legislator, indeed anything within the realm of law (or the realm of "legal"), cannot exist without values, culture, and society. The law is not an empty form: it bears cultural contexts and cannot exist beyond them. Without cultural forms, no one will understand the content of the law.

The law, culture, and society operate with concepts. Modern liberal democracies rest on many ideas that serve as a means of justification. These concepts are regularly contained in the Constitution (they are words like freedom, dignity, and democracy). The German sociologist Karl Mannheim (Mannheim 1966) described the emptiness of the fundamental ideological concepts of liberalism. Those concepts are - according to Mannheim - only frames for content, which has been purposely left undetermined (Mannheim 1966, 200). There is no general agreement on its content. These concepts can be used (as well as abused) then by different power holders to form a tangible regulation. Emptiness does not mean a vacuum. It means the content of ideological concepts of liberalism can be variably defined and used in many narratives surrounding (not only) the legislative process. The legislator can use them without material limits to achieve its political goals.

\section{CONCLUSION}

The legislative process is partly executed by administrative agencies. These stages are somewhat hidden before the eyes of science or democratic control. However, these stages are subject to informal regulation and narratives. The results of preliminary research on legal experts participating in legislation in the 
Czech Republic showed that the political assignments are less rational than was before, and any form and idea justifying the statute is welcomed (Škop et al. 2019). Mannheim's statement about the emptiness of concepts of liberalism was proved.

The emptiness of narratives explored by Streeck (2017) and the emptiness of liberal concepts presented by Mannheim (1966) highlight the main problem of legislation. A part of society shares both the law and cultural context. The bill should be interpreted and created concerning shared social experience handed down by language. Today, after emptying the main concepts and the challenge to the main narratives, the law has become open to any attack. The danger of attack is why it is so essential to observe the bureaucratic parts of the law-making process.

The real lawmaker is no more limited by constitutional principles because of their emptiness or rather unlimited applicability. Therefore it is crucial to follow formal rules regarding the legislative process and investigate its hidden administrative parts.

Earlier version of this article was presented at workshop „New constitutionalism? New forms of democracy and rule of law beyond liberalism", Oñati International Institute for the Sociology of Law, 12-13 July 2018. This article is a result of research funded by the Czech Science Foundation (GAČR), grant no. GA17-14903S - "Methodology of empirical research on the usage of interpretative methods in law-making".

\section{BIBLIOGRAPHY}

Althusser, Louis. 2014. On the Reproduction of Capitalism: Ideology and Ideological State Apparatuses. New York: Verso.

Bacon, Francis. 1785. Reading upon the Statute of Uses. London: E. Brooke, Bell Yard, Temple Bar. Baudrillard, Jean. 1994. Simulacra and Simulation. Ann Arbor: University of Michigan Press.

Bauman, Zygmunt. 1989. Modernity and Holocaust. Cambridge: Polity Press.

Benedict XVI. 2009. Caritas in veritate. http://w2.vatican.va/content/benedict-xvi/en/encyclicals/ documents/hf_ben-xvi_enc_20090629_caritas-in-veritate.html [accessed: February 29, 2020].

Benjamin, Walther. 1988. Illuminations. New York: Random House.

Bentham, Jeremy. 1843. The Works of Jeremy Bentham. Vol. 3. Edinburgh: William Tait.

Bielska-Brodziak, Agnieszka. 2017. Śladami prawodawcy faktycznego: materiały legislacyjne jako narzędzie wyktadni prawa. Warszawa: Wolters Kluwer.

Borowicz, Adam. 2009. "Argument interpretacyjny odwołujący się do woli rzeczywistego prawodawcy". Studia Prawno-Ekonomiczne 79: 9-28.

Bourdieu, Pierre. 1987. "The Force of Law: Toward a Sociology of Juridical Field". The Hastings Law Journal 38(5): 814-853.

Bourdieu, Pierre. 1991. Language and Symbolic Power. $7^{\text {th }}$ printing. Cambridge: Harvard University Press.

Bourdieu, Pierre. 1996. The Rules of Art: Genesis and Structure of the Literary Field. Stanford: Stanford University Press.

Bourdieu, Pierre. 1999. Outline of a Theory of Practice. $14^{\text {th }}$ printing. Cambridge: Cambridge University Press. 
Bourdieu, Pierre. 2001. Masculine Domination. Stanford: Stanford University Press.

Bourdieu, Pierre. Randal Johnson, 1993. The Field of Cultural Production: Essays on Art and Literature. New York: Columbia University Press.

Brooks, Peter. 2002. "Narrativity of the Law". Law and Literature 14(1): 1-10.

Calabresi, Guido. 1982. Common Law for the Age of Statutes. Cambridge: Harvard University Press.

Cohen, Stanley. 2011. Folk Devils and Moral Panics: the Creation of the Mods and Rockers. New York: Routledge.

Cover, Robert M. 1983. "Foreword: Nomos and Narrative". Harvard Law Review 97(1): 4-68.

Cover, Robert M. 1985. "Folktales of Justice: Tales of Jurisdiction”. Capital University Law Review 14(2): 179-204.

Dawkins, Richard. 1998. "Postmodernism Disrobed”. Nature 394(6689): 141-143.

Eco, Umberto. 1981. The Role of the Reader: Explorations in the Semiotics of Texts. Bloomington: Indiana University Press.

Foucault, Michel. 1979. Discipline and Punish: the Birth of the Prison. New York: Vintage Books. Geertz, Clifford, 1973. The Interpretation of Cultures: Selected Essays. New York: Basic Books.

Krygier, Martin. 1988. "The Traditionality of Statutes". Ratio Juris 20(1): 20-39.

Lukács, Georg. 1971. History and Class Consciousness: Studies in Marxist Dialectics. $6^{\text {th }}$ printing. Cambridge: MIT Press.

Lyotard, Jean-François. 1984. The Postmodern Condition: a Report on Knowledge. Minneapolis: University of Minnesota Press.

Mannheim, Karl. 1966. Ideology and Utopia: an Introduction to the Sociology of Knowledge. Reprinted. London: Routledge \& Kegan Paul.

Mańko, Rafał. 2018. W stronę krytycznej filozofii orzekania. Polityczność, etyka, legitymizacja. Łódź: Wydawnictwo Uniwersytetu Łódzkiego.

McKinley, Bob. 2000. "Postmodernism Certainly Is Not Science, but Could It Be Religion?" CSAS Bulletin 36(1): 16-18.

Montesquieu, Michel de. 1777. The Complete Works of M. de Montesquieu in Four Volumes. Volume the Second. The Spirit of Laws. Dublin: W. Watson et al.

Paulus, Ingeborg. 1974. The Search for Pure Food: a Sociology of Legislation in Britain. London: M. Robertson.

Robinson, Chester A. 1991. The Bureaucracy and the Legislative Process: a Case Study of the Health Care Financing Administration. University Press of America.

Savigny, Friedrich Karl von. 1999. Of The Vocation of our Age for Legislation and Jurisprudence. Kitchener: Batoche.

Smejkalová, Terezie. Martin Škop. 2017. “A Concept of a Reader in Legislation Drafting”. In Argumentation 2017. 51-69. Edited by Markéta Štěpáníková et al. Brno: Masaryk University.

Streeck, Wolfgang. 2017. "Caution: European Narrative. Handle with Care!" In European Union and Disunion: Reflections on European Identity. 14-22. Edited by Ash Amin, Philip Lewis. London: The British Academy.

Sullivan, Ruth. 2007. Statutory Interpretation. $2^{\text {nd }}$ edition. Ottawa: Irwin Law.

Škop, Martin. Barbora Vacková. 2019. "Být legislativcem: Empirická šetření v administrativních fázích legislativy". Časopis pro právní védu a praxi 27(1): 5-28.

Škop, Martin. Monika Hanych. Michal Malaník. Terezie Smejkalová. Markéta Štěpáníková. Barbora Vacková. 2019. Tvorba práva - Empirické studie. Brno: Masarykova Univerzita.

Tait, Allison. Luke Norris. 2011. "Narrative and the Origins of Law". Law and Humanities 5(1): 11-22.

Wronkowska, Sławomira. 1987. "The Rational Legislator as a Model of Real Lawmaker". In Polish Contributions to the Theory and Philosophy of Law. 179-188. Edited by Zygmunt Ziembiński. Amsterdam: Rodopi. 


\section{Martin $\check{S} k o p$}

\section{PROBLEMATYKA PROJEKTOWANIA USTAW - KILKA UWAG Z PERSPEKTYWY FILOZOFICZNEJ}

Streszczenie. Artykuł bada związki pomiędzy procesem stanowienia prawa a narracjami. Niewątpliwie, proces tworzenia ustaw jest kwestią konstytucyjną, ale Konstytucja porządkuje jedynie fragment tego procesu. Konstytucja, czy też inne ustawy, nie regulują części procesu legislacyjnego wdrażanego przez rząd (głównie w fazie wstępnej), jakkolwiek jest on ważny i wpływa na pozostałe jego etapy. Działanie rządu jawi się tu jako sfera nieformalnych regulacji ukrytych przed kontrolą społeczeństwa. W artykule bada się znaczenie biurokratycznych elementów procesu stanowienia prawa, kładąc nacisk na podejście narracyjne: to narracje uzasadniają prawodawstwo. Powstaje pytanie, jak możemy przezwyciężyć dualizm narracyjny - jeden determinowany interesami globalnej wspólnoty, drugi interesami poszczególnych państw?

Słowa kluczowe: ustawodawstwo, nowy konstytucjonalizm, narracje, biurokracja, projektowanie ustaw. 